\title{
INTRASPECIFIC VARIATION IN THE REPRODUCTIVE EFFORT AMONG THREE POPULATIONS OF AN INTERTIDAL GASTROPOD, Nerita japonica (Dunker)
}

\author{
(Variasi Indeks Kematangan Gonad Interspesies pada Tiga Populasi Gastropoda Intertidal, \\ Nerita japonica (Dunder))
}

\author{
Carolus P. Paruntu ${ }^{1}$ \\ ${ }^{1}$ Fakultas Perikanan dan Ilmu Kelautan Universitas Sam Ratulangi, Manado, Sulawesi Utara
}

\begin{abstract}
Penelitian ini bertujuan untuk mendeskripsikan indeks kematangan gonad dari gastropoda intertidal, Nerita japonica yang hidup di tiga habitat yang berbeda di Pulau Shimoshima Anakysa, Kyushu bagian barat, Jepang. Parameter yang diamati pada setiap populasi adalah: (a) Milat rata-rata berat kering gonad matang, (b) indeks kematangan gonad, dan (c) hubungan antara indeks kematangan gonad dan ukuran tubuh. Data dicatat pada periode musim pemijahan. Ketiga populasi memperlihatkan nilai rata-rata berat kering gonad yang matang dan indeks kematangan gonad yang betbeda. Populasi pantai berbatu memiliki nilai rata-rata berat kering matang gonad dan indeks kematangan gonad yang paling besar, diikuti oleh nilai dari populasi pantai berbatu bagian bawah dan pepułas pantai berbatu bagian atas memiliki nilai yang paling kecil. Selanjutnya, satu dari tiga populasi yaitu populasi pantai berbatu bagian atas memperlihatkan indeks kematangan gonad dari individu-individu betina $N$. japonica berhubungan dengan ukuran tubuhnya. Sekalipun indeks kematangan gónad ${ }^{\circ}$ dari individu-individu $N$. japonica meningkat secara signifikan dengan bertambahnya ukuran tubuh, namun terdapat variasi intraspesifik pada $N$. japonica dalam hal indeks kematangan gonad menurut habitat walaupun secara geografis berdekatan.
\end{abstract}

Kata kunci: ukuran tubuh matang kelamin, berat kering gomad matang, indeks kematangan gonad, variasi intraspesifik, Nerita japonica.

The aim of the present research is to figure out the reproductive effort of Nerita japonica occurring in three different intertidal habitats of Amakusa Shimoshima Island, western Kyushu, Japan. Rocky shore population and other two stong shore populations (the upper stony shore and the lower stony shore) were described based on: (a) its Inean mature gonad dry weight, (b) reproductive effort, and (c) the relationship between reproductive effort and body size. Data recorded in the period of spawning season. The results revealed that thete were mean mature gonad dry weight and reproductive effort variations among three snail populations. Mean mature gonad dry weight and reproductive effort were larger for the Rocky shore poptatation, intermediate for lower stone shore population, and smaller for the upper stone shore population 10 one out of three populations, i.e., the upper stone shore population, reproductive effort of mature females increased significantly with an increase in body size. The data showed that reproductive fefort is related to adult body size of $N$. japonica. There was an intraspecific variation in repreductive effort among three populations of $N$. japonica over even small geographic distances.

\footnotetext{
Keywords: mature body size, mature gonad dry weight, reproductive effort, intraspecific variation,
}

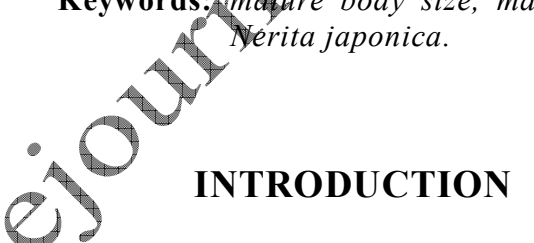

Studies on intra-specific variations in different habitats are important to understandding of life history patterns. Such studies are useful to determine whether differences among populations occur due to genetic differences among populations, environmental differences among habitats, or a combination of both. The reproductive efforts of intertidal animals vary with the food supply, nutrient availability, wa- ter stress, and shore height (Fletcher 1984). Variation among local subpopulations can be explained by local variation in both biotic and abiotic factors including food abundance, strength of competition, and habitat structures (Branch 1981).

The behavior, age, and growth of N.japonica have been also been documented as one of the intertidal macrobenthos in rocky shores of Hatakejima Island (Ohgaki, 2003). Recruitment success, change in density and distribution 
range of this species have been used as indicators for shore environmental conditions (Taka$\mathrm{da}, 2008)$. Variation in the morphometry of egg capsules and embryos, relationship between fecundity and sizes of capsules and embryos, and relationship between adult body size and reproductive traits of $N$. japonica have been found among eight local populations occurring in different intertidal habitats of Amakusa Shimoshima Island, western Kyushu, Japan (Paruntu and Tokeshi 2003). Intra and inter-specific variation in the morphometry of four intertidal gastropods species, i.e., Monodonta labio and N. japonica from western Kyushu, Japan, and $N$. polita and $N$. exuvia from Manado, Indonesia were investigated by Paruntu (2005). The growth rates of $N$. japonica occurring in three different intertidal habitat of Amakusa Shimoshima Island, western Kyushu, Japan were also investigated by Paruntu (2012). It is assumed, that individuals of $N$. japonica from different populations may show variation in reproductive effort, which may in turn be associated with body size. The aim of this study is to determine variation in reproductive effort among three local populations of $N$. japonica inhabiting different intertidal habitats of Amakusa Shimoshima Island, western Kyushu, Japan. Specifically, we focused on (1) variation in mean mature gonad dry weight, (2) reproductive effort and (3) relationship between reproductive effort and mature body size.

\section{MATERIALS AND METHODS}

\section{Study sites}

This research was established on the Tomioka Peninsula $\left(32{ }^{\circ} 3 \mathrm{~N}, 130^{\circ} 02^{\prime}\right.$ E) of Amakusa Shimoshima Island, south-western Japan (Fig. 1). One study site was set up on an exposed intertidafrocky (i.e., the upper Akaiwa rocky shore $1(\mathrm{R})$ ) ) and two study sites were on the moderately exposed intertidal stony shore (i.e., tyo tidal zones of the magarizaki stony shore 3 , the upper stony shore (S3u) and lower stony shore (S3l)) (Fig. 1). On the rocky shore 1 (RI), the upper zone was the only area that had been observed through preliminary study to show the presence $N$. japonica. It was found that the slope of this rocky was steep, whereas that of stony shore was gentle. Shore height difference between the lower $(\mathrm{S} 3 l)$ and upper (S3u) stony shores was $58 \mathrm{~cm}$, and that between the lower stony (S3l) and upper rocky (R1), the shores height was $71 \mathrm{~cm}$, whereas between the upper stony $(\mathrm{S} 3 u)$ and upper rocky (R1) shores was $13 \mathrm{~cm}$. It was found that between the upper rocky (RI) and upper stony (S3u) shores, there was no significant shore height difference. For a general description of these shores, see Mori and Tanaka (1989), Takada and Kikuchi (1990), Paruntu and Tokeshi (2003), Paruntu (2005), and Paruntu (2011).

\section{Size at maturity and reproductive effort}
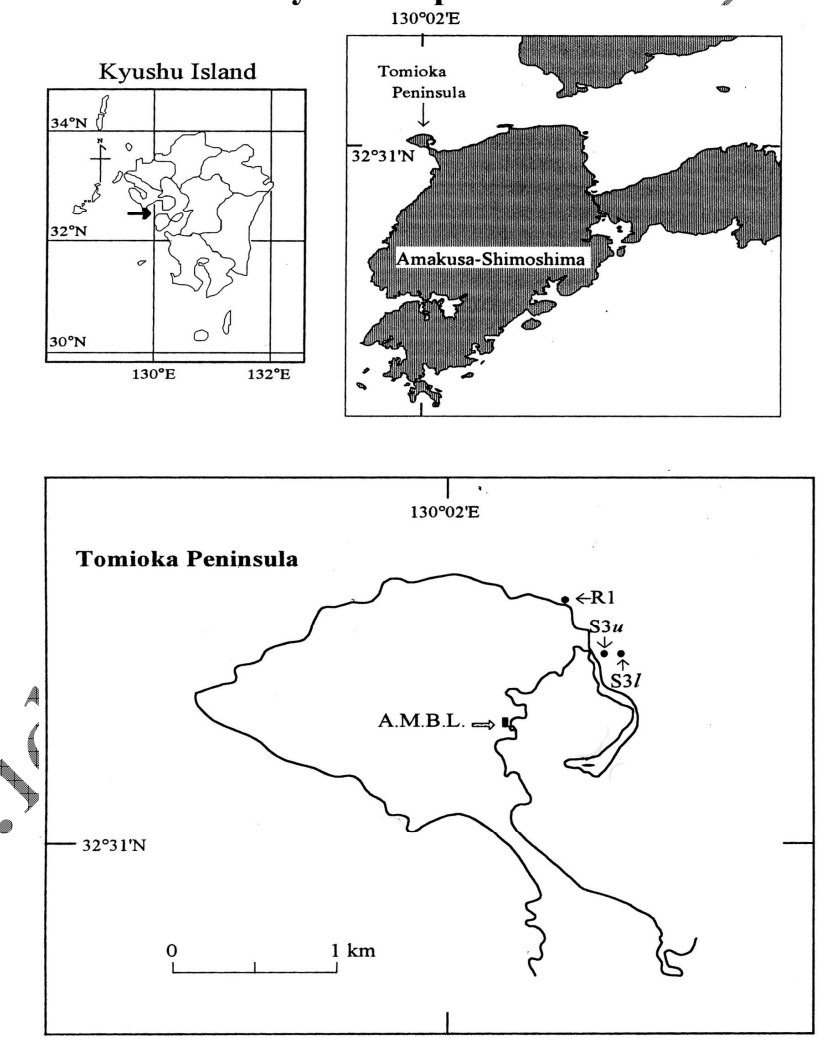

Figure 1. Map of study area. Location of sampling sites (R1, S3u, and S3l). AMBL: Amakusa Marine Biological Laboratory, Kyushu University.

Shell length at which snails become sexually mature, mature gonad dry weight and reproductive effort (i.e., the proportion of mature gonad dry weight out of the total body tissue dry weight) were investigated for the upper rocky (R1), upper stony (S3u), and lower stony ( $33 l)$ shore populations to determine if size at maturity, mature gonad dry weight and the reproductive effort varied among populations. Approximately 100 snails over a size range ( $>7$ $\mathrm{mm}$ in shell length) were collected by hand and forceps at each site in the period of spawning season, i.e., late April to early May 2002. This size range was used because preliminary observation indicated the maturation size of the overall populations was bigger than $7 \mathrm{~mm}$. Snails with mature gonads (i.e., yellow ovary with 
white crystal sac) and without the cephalic penis were considered to be mature females $N$. japonica (Fig. 2a, b). On the other hand, snails with yellow gonad testis and the cephalic penis were considered to be mature males $N$. japonica (Fig. 2c,d).

Snails were steamed for 3-5 minutes and the whole soft body tissues were removed from the shells. Mature female and male gonads were separated out of the whole soft body tissues under a dissecting microscope. Whenever, mature male gonads were difficult to be separated out of the whole body tissues, and then they were obtained by omitting seminal vesicle and testis parts (Fig. 2e). The female and male shells, soft body tissues (out of gonad), and gonads were dried at $60^{\circ} \mathrm{C}$ for $72 \mathrm{~h}$ to obtain dry weight of shell, soft body tissue, and gonad of each individual. Then the female and male shells were measured by using a digital electronic caliper to $0.01 \mathrm{~mm}$ precision. Whereas total dry weight of the body tissues of female and male snails were derived as the dry weight of soft body tissues of female and male plus the dry weight of mature female or male gonads, respectively.

An ANOVA was used to detect if mature body sizes and mature gonad dry weight varied among three populations (Sokal \& Rohlf 1995). If significant effect was detected, Tukey-Kramer multiple comparisons test was employed to separate out which pairs of samples actually differed. Furthermore, the data of reproductive effort and mature body size were transformed to arcsine and patural logarithms, respectively, to stabilize the variances. These transformed data were then analyzed by regression analysis to examine reproductive effortmature body size relationship and by ANOVA and Tukey-Kramer test to detect difference in reproductive efforta among sites.

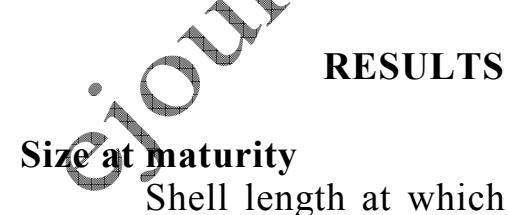

came sexually mature and mean fen tion size varied among three populations (Table 1). Female snails in the $S 3 u$ population began to mature by $7.9 \mathrm{~mm}$, while female snails from the $\mathrm{R} 1$ and $\mathrm{S} 3 l$ did not mature until $10.4 \mathrm{~mm}$ and $10.1 \mathrm{~mm}$, respectively. The $\mathrm{R} 1$ population had the largest mean female maturation size (14.8 $\mathrm{mm}), \mathrm{S} 3 l$ population had intermediate mean female maturation size $(12.3 \mathrm{~mm})$, while the S3 $u$ population had the smallest mean female maturation size $(9.1 \mathrm{~mm})$ (Tukey-Kramer test, $P<0.0001)$. Furthermore, shell lengths at which male snails became sexually mature and mean male maturation size also varied among three populations (Table 1). Male snails in the S3u population began to mature by $7.5 \mathrm{~mm}$, while male snails from the $\mathrm{R} 1$ and $\mathrm{S} 3 l$ did not mature until $9.4 \mathrm{~mm}$ and $9.7 \mathrm{~mm}$, respectively. The R1 population had the largest mean male maturation size $(13.6 \mathrm{~mm}), \mathrm{S} 3 l$ population had intermediate mean male maturation size $(1.7 \mathrm{~mm})$, while the $\mathrm{S} 3 u$ population had the smallest mean male maturation size ( $8.8 \mathrm{~mm}$ ) (Tykey-Kramer test, $P<0.0001$ ).

\section{Reproductive effort}

Mean mature female gonad dry weight varied among three populations (Table 1). The R1 population hade the largest mean mature female gonadgdry weight $(0.022 \mathrm{~g}), \mathrm{S} 3 l$ population had internediate mean mature female gonad dry weight $(0.013 \mathrm{~g})$, while the $\mathrm{S} 3 u$ population had the smallest mean mature female gonad dty weight $(0.003 \mathrm{~g})$ (Tukey-Kramer test, Pł0.0001). Furthermore, mean mature male gonad dry weight also varied among three populations (Table 1). Mean mature male gonad dry weight was larger for the R1 population $(0.008$ $\mathrm{g})$, intermediate for $\mathrm{S} 3 \mathrm{l}$ population $(0.005 \mathrm{~g})$, and smaller for $\mathrm{S} 3 u$ population $(0.001 \mathrm{~g})$ (Tukey-Kramer test, $P<0.0001$ ).

Relationship between reproductive effort of mature females (arcsine-transformed percentage values) and its log shells length was investigated among three populations (Fig. 3a). Regression lines from the $\mathrm{R} 1$ and $\mathrm{S} 3 l$ populations were not signifycant indicating that reproductive effort of mature females from each of the two populations did not change with snail size, while regression line from the $\mathrm{S} 3 u$ population was significant, indicating that the reproductive effort of mature females increased with its snail size. Tukey-Kramer test revealed that reproductive effort of the $\mathrm{R} 1>\mathrm{S} 3 u, \mathrm{~S} 3 l>\mathrm{S} 3 u$, while the $\mathrm{R} 1=\mathrm{S} 31 \quad(P<0.0001)$. Relationship between reproductive effort of mature male individuals (arcsine-transformed percentage values) and its $\log$ shells length was also investigated among three populations (Fig. 3b). Regression lines from all three populations were not significant, indicating that reproducetive effort of mature males from each of three popula- 
tions did not change with its snail size. TukeyKramer test revealed that reproductive effort of the $\mathrm{R} 1>\mathrm{S} 3 u, \mathrm{~S} 3 l$, and $\mathrm{S} 3 l>\mathrm{S} 3 u(P<0.0001)$.

Table 1. Mature body size range, mean mature body size ( \pm S.D.), mean mature gonad dry weight ( \pm S.D.) for three populations

\begin{tabular}{|c|c|c|c|c|c|}
\hline Site & $\begin{array}{c}\text { Mature body } \\
\text { size range } \\
\text { (mmin) }\end{array}$ & $\begin{array}{l}\text { Mean matur } \\
\text { body size } \\
\text { (mam) }\end{array}$ & & $\begin{array}{l}\text { Mean mafure } \\
\text { gonad dry weigl } \\
\text { (g) }\end{array}$ & \\
\hline \multicolumn{6}{|c|}{ Female: } \\
\hline RI & $10.43 .16 .15(28)$ & $14.84 \pm 1.10(28)$ & & $0.022 \pm 0.005(28)$ & \\
\hline $\mathrm{S} 3 u$ & $7.87-11.29(27)$ & $9.14 \pm 0.82(27)$ & & $0.003 \pm 0.001(28)$ & \\
\hline $\mathrm{s} 3 /$ & $10.09-13.96(24)$ & $12.34 \pm 1.04(24)$ & $\leftrightarrow * * \bullet$ & $0.013 \pm 0.004(24)$ & $\bullet \bullet \bullet+$ \\
\hline \multicolumn{6}{|c|}{ Male: } \\
\hline RI & $9.38-16.13(16)$ & $13.56 \pm 2.29(16)$ & & $0.008 \pm 0.004(16)$ & \\
\hline $\mathrm{S} 3 u$ & $7.54-16.13(16)$ & $8.76+0.68(23)$ & & $0.001 \pm 0.0003(23)$ & \\
\hline s3l & $9.70-13.73(33)$ & $11.67 \pm 0.99(33)$ & $* * * *$ & $0.005 \pm 0.001$ (35) & $* * * *$ \\
\hline
\end{tabular}

The number in the parenthesis represents the number individuals examined. Asterisks indicate that the values are significantly different among three populations (TukeyKramer test, $* * * * P<0.0001)$.

\section{DISCUSSION}

Three populations of $N$. japonica differed markedly in many of the population variables measured during this study. Size at which snails mature and maximum body size are linked because $N$. japonica tends to cease growth at maturity. Maximum body size of snails varied among shores with snails from the S3u popula tion ceasing growth at small size, snails from the $\mathrm{S} 3 \mathrm{l}$ population ceasing growth at intermediate size, while snails from the R (population ceasing growth at large sizes (Paruntu 2012).

The reproductive efforfof an organism is measured by energy budgets and gonad to body weight ratios, both of them gave similar result for limpet found by Parry (1982). This is supported by Spivat et al. (2012) who studied the intertidal crabs that energy demands inflicted by harsh environmental conditions could also affect the reproduction. In the present stu$\mathrm{dy}$, we used-the proportion of mature female or male gonad dry weight out of total body tissue dry weight as a measure of the reproductive effort of individuals from three intertidal shore populations of $N$. japonica.

Reproductive effort of an individual or species may or may not increase allometrically with age. The reproductive effort of the Cellana tramoserica individuals within a population was found to be independent of age (Fletcher 1984). This study found that the reproductive effort of female or male individuals from all three populations was not different over the size range (except the reproductive effort of female individuals from the $\mathrm{S} 3 u$ population).

Differences in reproductive effort, mature female and male gonad dry weight, and the packaging of embryos among sites, populations appeared to differ in the allocation of energy to offspring. Fecundity data suggest that the largest reproductive effort from the largest R1 shore snails invest the greatest energy to offspring per capsule, while that from the smallest S3u shore snails invest the smallest (Paruntu and Tokeshi 2003). This is similar to the pattern for Cellana tramoserida, where reproductive effort was related to body size at a site (Fletcher 1984).

Intraspecific competition at increased density has been found to result in a reduction in tissue in some gastropods whereas in Cellana tramoserica it has been found to result in a reduction of gonad weight (Fletcher 1984). in the present study, the R1 population had the greatest reproductive effort and smallest density, and probably the greatest availability of food. Conversely, the S3u population had the smallest reproductive effort and greatest density, and probably the smallest availability of food. This is similar to the pattern for Cellana tramoserica, where reproductive effort was related to density at a site (Fletcher 1984).

This study demonstrates that $N$. japonica showed noticeable variation in their reproductive efforts even within geographically small distances. Such variability in the basic traits of a species must have important implycations for their life history strategy. Future studies, however, are still needed to clarify whether the differences in reproductive effort of $N$. japonica among those populations were due to environmental differences among habitats, genetic differences among populations, or a combination of both.

\section{ACKNOWLEDGEMENTS}

I would like to thank Prof. M. Tokeshi, Dr. S. Nojima, Mr. A. Harahap, Dr. B. Wagey and all members of the AMBL Kyushu University for helpful advice and encouragement throughout this research, and critical reading of this paper. 


\section{REFERENCES}

Branch GM. 1981. The biology of limpets: physical factors, energy flow, and ecological interaction. Oceanography and Marine Biology Annual Review, 19: 235380 .

Fletcher WJ. 1984. Variability in the reproductive effort of the limpet, Cellana tramoseria. Oecologia (Berlin), 61: 259-264.

Mori K, Tanaka M. 1989. Intertidal community structures and environmental condition of exposed and sheltered rocky shores in Amakusa, Japan. Publications from the Amakusa Marine Biological Laboratory Kyushu University, 10: 41-46.

Ohgaki SI. 2003. Distribution of Intertidal Macrobenthos Around Hatakejima Island. Argonauta 9: 21-34.

Parry GD. 1982. Reproductive effort in four species of intertidal limpet. Marine Biology, 67: 267-282.

Paruntu CP. 2005. Intra and inter-specific variations in the morphometry of four intertidal gastropod species. J. Perikanan dan Ilmu Kelautan, 1 (1): 44-55.
Paruntu CP. 2011. Intraspecific Variation in Growth Rate among Three Populations of the Intertidal Gastropod, Nerita japonica (Dunker). Biota, 16(2): 316-324.

Paruntu CP, Tokeshi M. 2003. Variability in the reproductive characteristic of local populations of an intertidal gastropod, Nerita japonica (Dunker). Benthos Research, 58 (1): 7-14.

Sokal RR. and Rohlf FJ. 1995. Biometry (Third Edition). W. H. Freeman and Company, New York. 887 p.

Spivak ED, Silva PV, Lippi TA, 2012. Habitat Related Variation In Reproduction Traits Among Intertidal Crabs From Southwestern Atlantic. J. Crush Biol. 32(1): 57-66.

Takada Y, Kikuchi T. 1990. Mobile molluscah communities in boulder shores and the comparison with other intertidal habitats in Amakusa. Publications from the Amakusa Marine Biological Laboratory Kyushu University, 10: 145-168.

Takada Y. 2008. Contrasting Chafacteristics In Increasing and Decreasing Phases of Nerita japonica (Mollusca: Gastropoda) Population On Boulder Shore. Pop. Ecol. 50: 391-403.

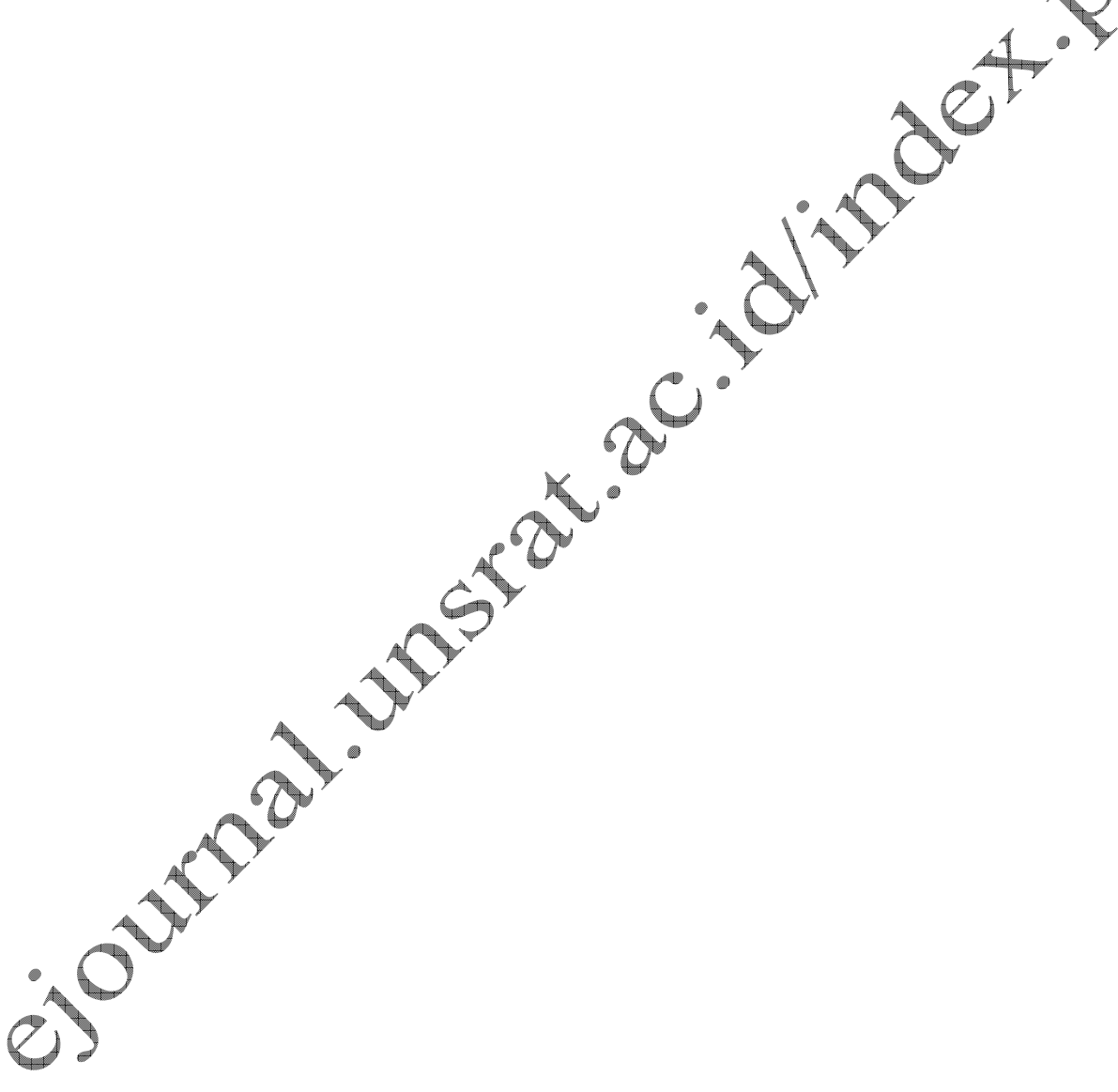




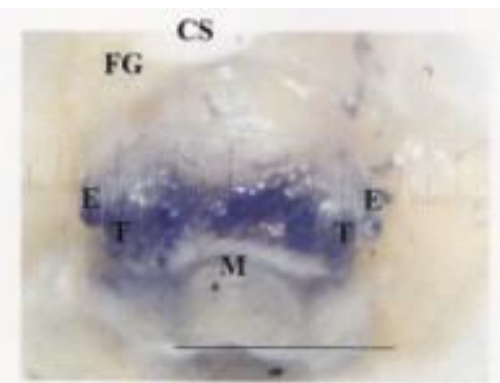

(a) A female with mature gonad ovary and white crystal sac

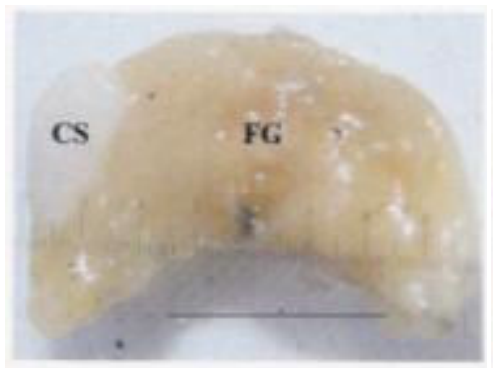

(b) Mature female gonad with white crystal sac

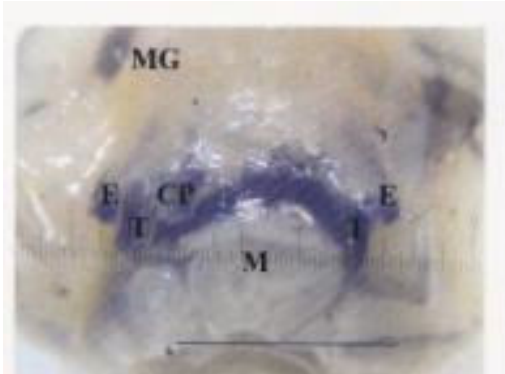

(c) A male with mature gonad testis and the cephalic penis

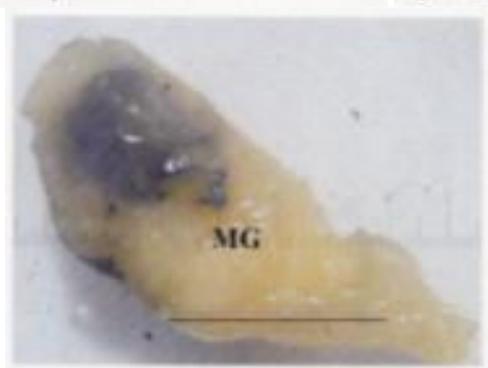

(d) Mature male gonad with seminal vesicle and testis parts (brown negion)

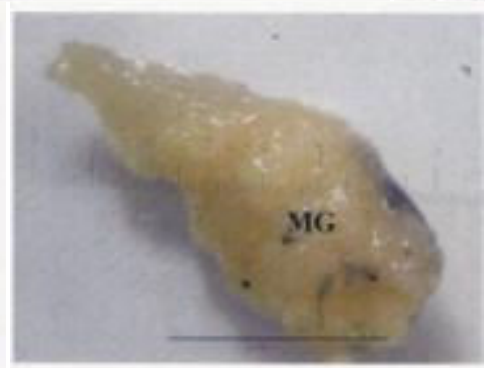

(c) Mature male gonad (omitting seminal vesicle and testis parts)

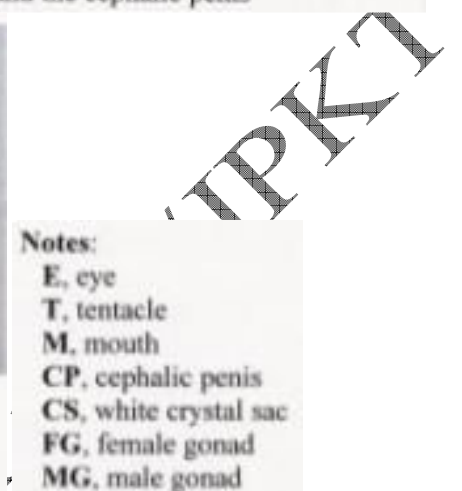

Figure 2. Reproductive organs of Nerita japonica, scalè bar $=4 \mathbf{m m}$.
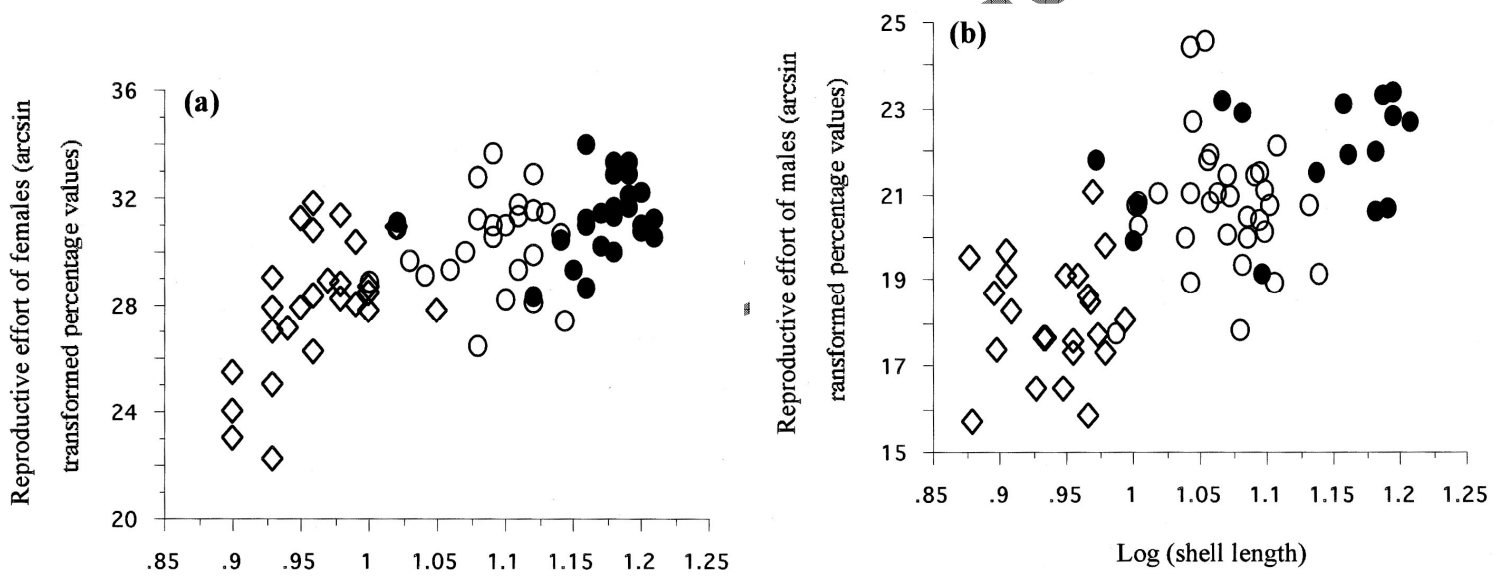

Figure 3. Relationship between (a) mature female gonad dry weight as a percent of total body tissue dry weight (reproductive effort) and its log shell length, (b) mature male gonad dry weight as a percent of total body tissue dry weight (reproductive effort) and its log shell length of $N$. japonica. NS, P>0.05. n, number of individuals examined.

(a) Regressionspane:

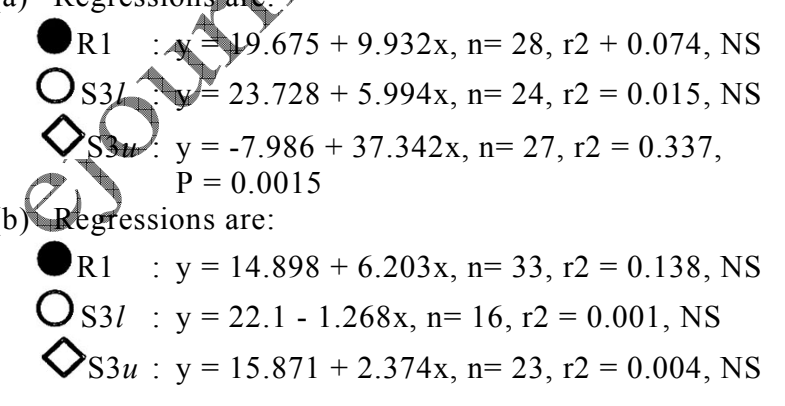

